\title{
PENGARUH MEDIA PEMBELAJARAN ASAM BASA BERBASIS ANDROID TERHADAP EFIKASI DIRI PESERTA DIDIK
}

\author{
Tika Rahmawati ${ }^{{ }^{*}}$ dan Crys Fajar Partana ${ }^{\mathbf{1}}$ \\ ${ }^{1}$ Program Studi Pendidikan Kimia, Program Pascasarjana, \\ Universitas Negeri Yogyakarta, Jalan Colombo No. 1, Karangmalang, Yogyakarta \\ 55281, Indonesia \\ *E-mail: tikarahmawaty@gmail.com
}

\begin{abstract}
ABSTRAK
Penelitian mengenai penerapan media pembelajaran android ini bertujuan untuk mengetahui dampak media pembelajaran android terhadap efikasi diri peserta didik pada materi asam dan basa. Jenis penelitian ini merupakan penelitian quasi-eksperimen dengan desain post-test only. Populasi penelitian terdiri dari peserta didik SMAN 5 Yogyakarta kelas XI. Teknik pengambilan sampel adalah random sampling. Sampel terdiri dari dua kelompok yaitu kelas eksperimen dan kontrol. Peserta didik pada kelas eksperimen mengikuti proses pembelajaran menggunakan media pembelajaran berbasis android sedangkan peserta didik pada kelas kontrol melakukan pembelajaran konvensional. Instrumen pengumpulan data dalam penelitian ini adalah angket efikasi diri yang terdiri dari 28 butir pernyataan. Data skor efikasi diri peserta didik dianalisis menggunakan ANOVA dengan SPSS versi 24.0. Hasil penelitian menunjukkan bahwa efikasi diri peserta didik yang mengikuti proses pembelajaran menggunakan media pembelajaran berbasis android lebih baik daripada peserta didik yang melakukan pembelajaran konvensional. Penerapan media pembelajaran android dapat meningkatkan efikasi diri peserta didik pada materi asam dan basa.
\end{abstract}

Kata kunci: asam basa, efikasi diri, media pembelajaran, pembelajaran kimia

\begin{abstract}
Research on the application of android learning media aims to find out the effect of android learning media on students' self-efficacy in acid and base material. This research was a quasi-experimental study with post-test only design. The population was the eleventh grade students of State Senior High School 5 Yogyakarta. The sampling technique is random sampling. Samples are classified into two groups, namely the experimental class and the control class. Students in the experimental class follow the learning process using learning media based on android while students in the control class learned through the conventional learning. The instrument of data collection in this study was a self-efficacy questionnaire consisting of 28 items. The data were analyzed by using ANOVA with SPSS version 24.0. The results showed that students' self-efficacy which follows the learning process using learning media based on android is better than students who learned through the conventional learning. The use of android learning media can improve student self-efficacy.
\end{abstract}

Keywords: acid base, self-efficacy, learning media, chemistry learning

DOI: http://doi.org/10.15575/jtk.v4i2.5022 


\section{PENDAHULUAN}

Perkembangan teknologi abad 21 menuntut pendidik untuk menguasai keterampilan abad 21 berupa memahami dan memanfaatkan teknologi informasi dan komunikasi (ICT literacy skills) dalam pembelajaran. Kemampuan literasi ICT pendidik bermanfaat untuk mendesain pembelajaran yang kreatif dan inovatif. Kemampuan mengajar pada era digital perlu dipersiapkan dengan pedagogi siber pada diri pendidik. Pendidik yang lebih banyak berperan sebagai fasilitator harus mampu memanfaatkan teknologi digital yang ada untuk mendesain pembelajaran kreatif dan inovatif untuk dapat membuat peserta didik aktif dan berpikir kritis (Evinola, 2019). Adanya teknologi dalam pembelajaran dapat meningkatkan minat peserta didik, hasil belajar peserta didik, kemampuan berpikir kritis, dan kemampuan pemecahan masalah peserta didik. Berdasarkan fakta di lapangan, pembelajaran di Indonesia masih kurang memanfaatkan teknologi. Penelitian yang dilakukan Rivalina (2014) menunjukkan bahwa sebagian pendidik memiliki kendala dalam melaksanakan pembelajaran berbasis teknologi diantaranya adalah kurangnya penguasaan teknologi yang dimiliki oleh pendidik, fasilitas yang disediakan oleh sekolah kurang memadai, dan padatnya jam mengajar pendidik di sekolah.

Penggunaan perangkat seluler dalam pembelajaran atau mobile learning mampu membantu peserta didik dalam mengakses materi tanpa terikat ruang dan waktu serta mendukung interaksi yang lebih dekat antara pendidik dan peserta didik (Baran, 2014). Kelebihan perangkat seluler ini menjadikan tantangan untuk mengembangkan dan mengimplementasikannya dalam proses pembelajaran. Pembelajaran seluler menyediakan berbagai program aplikasi yang dapat diakses oleh peserta didik salah satunya adalah smartphone. Smartphone memiliki potensi sebagai media pembelajaran yang dapat mempengaruhi proses pembelajaran (Sung et al., 2016; Zheng et al., 2015).

Penggunaan smartphone biasanya disertai dengan penggunaan aplikasi android. Aplikasi android merupakan perangkat yang dapat mendukung proses pembelajaran dan dapat meningkatkan proses pembelajaran yang menekankan pada pemahaman konsep peserta didik (Shanmugrapiya, 2012). Beberapa penelitian menyatakan bahwa perangkat berbasis android dapat dimanfaatkan sebagai media pembelajaran yang mendukung proses pembelajaran, meningkatkan motivasi belajar, performa akademik peserta didik, dan hasil belajar peserta didik (Lubis \& Ikhsan, 2015; Shabrina \& Kuswanto, 2018; Yektyastuti \& Ikhsan, 2016). Namun kenyataannya, perkembangan smartphone yang sangat pesat ini tidak dimanfaatkan sebagai media pembelajaran oleh sebagian besar pendidik kimia. Pendidik kimia hanya menggunakan buku cetak kimia dan LKS kimia dalam pembelajarannya sehingga peserta didik cenderung pasif dan tidak menumbuhkan minat belajar peserta didik (Anisa \& Yuliyanto, 2017). Hal ini dapat memicu adanya kesalahpahaman konsep kimia peserta didik karena sejumlah konsep yang abstrak dan hasil belajar kimia peserta didik yang kurang maksimal (Özmen et al., 2009).

Berdasarkan hasil obsevasi proses pembelajaran kimia di SMAN 5 Yogyakarta diketahui bahwa pendidik masih belum maksimal dalam penggunaan media pembelajaran berbasis teknologi. Pendidik lebih sering menggunakan media pembelajaran berupa buku kimia dan LKS. Media pembelajaran berbasis teknologi yang digunakan hanya power point. Penggunaan power point dalam pembelajaran juga jarang dilakukan. Hal ini disebabkan karena pendidik 
memiliki kendala dalam penggunaan media pembelajaran berbasis teknologi. Selain itu, pembelajaran masih berpusat pada pendidik sehingga peserta didik kurang aktif.

Pembelajaran kimia merupakan pembelajaran yang mengembangkan kompetensi peserta didik dalam memahami konsep kimia secara sistematis melalui pembelajaran bermakna (Suyanti, 2010). Pembelajaran kimia menekankan peserta didik untuk belajar aktif dan terlibat secara langsung dalam pembelajaran sehingga mampu meningkatkan pemahaman konsep kimia dan memenuhi standar kompetensi lulusan (Chairam et al., 2015). Penelitian yang dilakukan oleh Lubis $\&$ Ikhsan (2015) menunjukkan bahwa pembelajaran kimia dalam kelas tidak menyenangkan dan membosankan sehingga peserta didik memiliki kesulitan dalam memahami materi kimia. Hal ini menyebabkan menurunnya hasil belajar peserta didik pada materi kimia. Selain itu berdasarkan aplikasi PAMER UN menyatakan bahwa hasil ujian nasional kimia SMA/MA di Indonesia tahun pelajaran 2017/2018 memperoleh rata-rata sebesar 50,83 . Rendahnya pemahaman peserta didik tersebut perlu adanya solusi yang efektif guna mengoptimalkan pemahaman peserta didik dan memotivasi peserta didik dalam memahami materi kimia (Kemendikbud, 2018).

Kesulitan peserta didik dalam mempelajari materi kimia juga dipengaruhi oleh efikasi diri peserta didik. Menurut Santrock (2011), efikasi diri merupakan keyakinan akan kemampuan seseorang dalam mengatur dan melaksanakan tindakan yang diperlukan untuk mencapai hasil yang diinginkan. Efikasi diri yang dimiliki peserta didik memiliki pengaruh yang signifikan terhadap hasil belajar peserta didik. Peserta didik dengan efikasi diri tinggi mempersiapkan diri dengan belajar yang baik sehingga diperoleh hasil belajar kognitif yang baik pula (Wahdania, dkk., 2017). Baanu et al.
(2016) menyatakan bahwa penyediaan bahan laboratorium kimia yang memadai, lingkungan kelas yang kondusif, dan media pembelajaran kimia yang memadai dapat mempengaruhi efikasi diri peserta didik.

Salah satu materi kimia yang memerlukan efikasi diri tinggi untuk meningkatkan hasil belajar peserta didik adalah larutan asam basa. Larutan asam basa merupakan prasyarat untuk mempelajari materi larutan penyangga dan larutan hidrolisis. Rendahnya hasil belajar materi larutan penyangga dan materi larutan hidrolisis dipengaruhi oleh materi larutan asam basa (Purnama dkk., 2016). Larutan asam basa mengandung representasi makroskopis, mikroskopis, dan simbolik. Kompleksnya cakupan materi asam basa menyebabkan peserta didik sering mengalami miskonsepsi (Amry dkk., 2017) sehingga hasil belajarnya rendah. Selain itu, LKS kimia yang digunakan pendidik kurang mendukung reprensentasi pada materi larutan asam basa. Dalam pembelajaran kimia materi asam dan basa, media pembelajaran android dapat dimanfaatkan juga untuk praktikum sederhana secara digital pada penentuan sifat larutan dengan kertas lakmus. Praktikum digital ini tidak menggunakan alat dan bahan secara nyata. Oleh karena itu, penelitian ini dinilai perlu untuk menerapkan media pembelajaran kimia android pada materi asam dan basa yang menunjang pemahaman materi peserta didik dan meningkatkan efikasi diri peserta didik.

\section{METODE PENELITIAN}

Penelitian ini menggunakan penelitian quasieksperimen dengan desain post-test only. Desain penelitian tertera pada Tabel 1 . Penelitian ini menggunakan dua kelas yaitu kelas ekperimen dan kontrol. Peserta didik pada kelas eksperimen mengikuti pembelajaran dengan media pembelajaran 
berbasis android sedangkan peserta didik pada kelas kontrol melakukan pembelajaran konvensional.

Tabel 1. Desain Penelitian

\begin{tabular}{|l|c|c|c|}
\hline \multicolumn{1}{|c|}{ Kelas } & Pre-test & Perlakuan & Post-test \\
\hline Eksperimen & - & $\mathrm{X}_{1}$ & $\mathrm{Q}_{1}$ \\
\hline Kontrol & - & $\mathrm{X}_{2}$ & $\mathrm{Q}_{1}$ \\
\hline
\end{tabular}

\section{Keterangan:}

$\mathrm{X}_{1}$ : pembelajaran kimia menggunakan media pembelajaran android

$\mathrm{X}_{2}$ : pembelajaran kimia tanpa menggunakan media pembelajaran android

$\mathrm{Q}_{1}$ : angket efikasi diri

Populasi pada penelitian ini merupakan peserta didik kelas XI MIPA SMAN 5 Yogyakarta. Teknik pengambilan sampel adalah random sampling. Sampel pada penelitian ini yaitu XI MIPA 5 sebagai kelas eksperimen yang berjumlah 32 peserta didik dan XI MIPA 6 sebagai kelas kontrol yang berjumlah 33 peserta didik. Penelitian ini dilakukan pada semester genap tahun akademik 2018/2019.

Instrumen pengumpulan data yang digunakan adalah angket efikasi diri. Angket efikasi diri terdiri dari lima aspek yaitu penyelesaian tugas, keyakinan, ketekunan, usaha dan pencapaian yang dijabarkan menjadi 28 pernyataan berupa pernyataan positif dan pernyataan negatif. Angket efikasi diri dikembangkan berdasarkan indikator efikasi diri yang diadaptasi dari Santrock (2011) dan Eggen \& Kauchak (2010).

Data efikasi diri peserta didik yang telah diperoleh selanjutnya dianalisis menggunakan One Way ANOVA dengan bantuan program SPSS versi 24. Uji ShapiroWilk digunakan untuk mengetahui distribusi data normal atau tidak sedangkan Levene's Test digunakan untuk mengetahui homogenitas data varians sebagai uji prasyarat. Uji ANOVA dilakukan untuk mengetahui perbedaan signifikan pada efikasi diri peserta didik di kelas eksperimen dan kelas kontrol.

\section{HASIL DAN PEMBAHASAN}

Media pembelajaran kimia yang dapat dioperasikan dengan aplikasi android ini digunakan untuk memudahkan peserta didik dalam mempelajari materi dan meningkatkan efikasi diri peserta didik. Media pembelajaran yang digunakan pada penelitian ini sebelumnya sudah dikembangkan menggunakan model pengembangan ADDIE. Media pembelajaran android ini juga telah melalui validasi oleh ahli materi, ahli media, pendidik kimia dan peer reviewer dengan kriteria sangat baik. Tampilan media pembelajaran yang telah dikembangkan dapat dilihat pada Gambar 1, 2, dan 3.

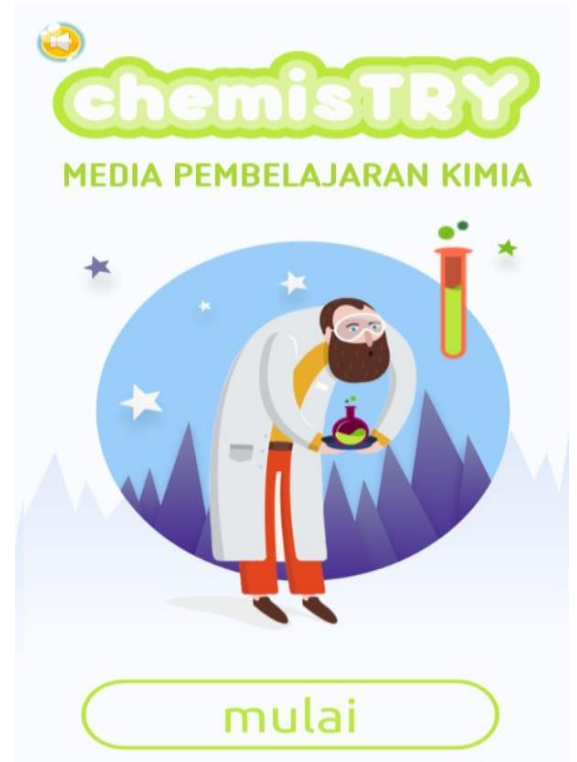

Gambar 1. Halaman Awal Media Pembelajaran Android 

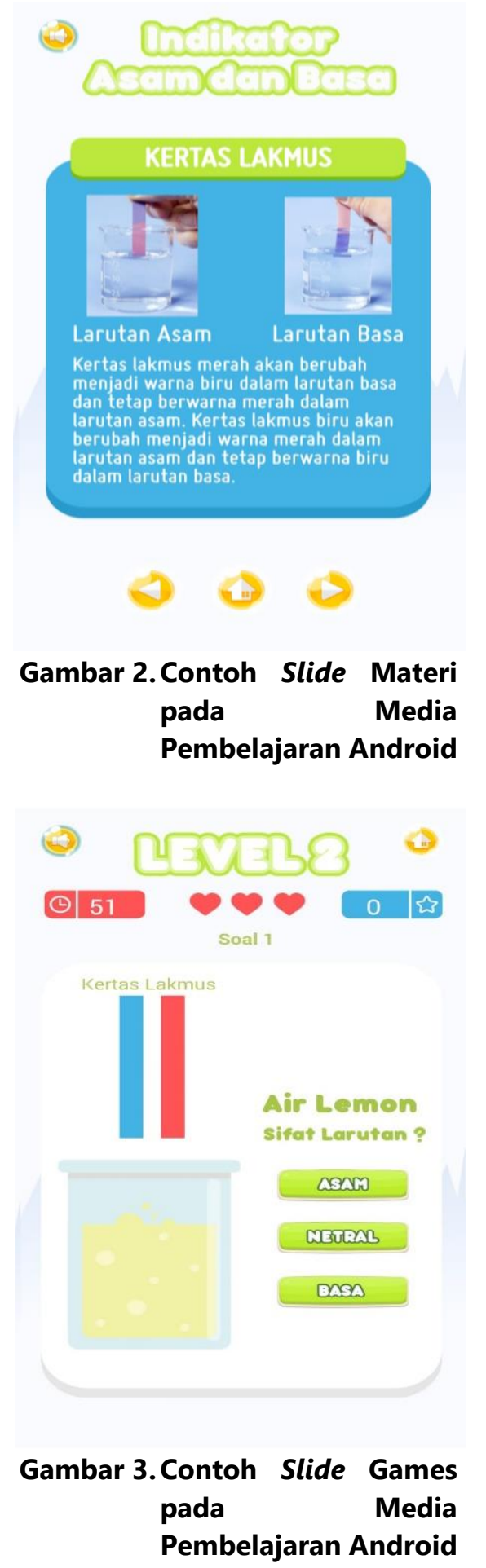

Data hasil penelitian yang dilakukan diperoleh skor post-test efikasi diri pada kelas eksperimen dan kelas kontrol. Data skor efikasi diri diperoleh dari angket efikasi diri sebanyak 28 butir pernyataan yang digunakan sebagai posttest setelah masing-masing kelas diberikan perlakuan. Distribusi efikasi diri peserta didik pada kelas eksperimen dan kelas kontrol ditunjukkan pada Tabel 2.

Tabel 2. Distribusi Skor Efikasi Diri Peserta Didik

\begin{tabular}{|l|c|c|c|c|}
\hline \multicolumn{1}{|c|}{ Kelas } & N & $\begin{array}{c}\text { Nilai } \\
\text { tertinggi }\end{array}$ & $\begin{array}{c}\text { Nilai } \\
\text { terendah }\end{array}$ & $\begin{array}{c}\text { Skor } \\
\text { rerata }\end{array}$ \\
\hline Eksperimen & 33 & 108,14 & 50,56 & 85,38 \\
\hline Kontrol & 32 & 103,07 & 48,06 & 77,00 \\
\hline
\end{tabular}

Hasil skor rerata efikasi diri peserta didik yang menerapkan pembelajaran dengan media pembelajaran android memiliki skor rata-rata 85,38 sedangkan peserta didik yang melakukan pembelajaran konvensional memiliki skor rerata sebesar 77 . Tingginya efikasi diri peserta didik pada kelas eksperimen disebabkan karena media pembelajaran android pada materi asam basa ini menyajikan materi pembelajaran yang menarik. Materi yang terdapat dalam media pembelajaran antara lain teori asam dan basa menurut ahli, pH larutan, indikator asam dan basa serta kekuatan asam dan basa. Selain itu, games yang terdapat dalam media ini terdiri dari empat level permainan dari mudah ke sulit. Level pertama berisi permainan memasangkan kartu nama senyawa dan rumus kimianya. Level kedua berisi permainan untuk menentukan sifat larutan dengan kertas lakmus. Level ketiga berisi permainan benar dan salah mengenai kekuatan asam dan basa. Level keempat berisi latihan soal materi asam dan basa. Media ini juga menyajikan ilustrasi yang menarik yang dapat membantu mengkonkritkan atau menyederhanakan materi asam dan basa yang bersifat abstrak dan mudah dipahami peserta didik.

Efikasi diri peserta didik juga dapat mempengaruhi hasil belajar peserta didik. Peserta didik yang memiliki skor rerata efikasi diri tinggi memiliki rerata nilai hasil belajar yang tinggi pula. Hasil penelitian serupa juga menyatakan bahwa efikasi diri memberikan 
pengaruh terhadap hasil belajar peserta didik (Ramnarain \& Ramaila, 2018). Peserta didik dengan efikasi diri tinggi merasa senang jika diberikan soal yang menantang dan merasa puas dengan hasil pekerjaannya. Hal ini disebabkan karena peserta didik dengan efikasi diri tinggi memiliki keyakinan yang tinggi pada kemampuannya untuk meghadapi tantangan sehingga peserta didik pada kelas eksperimen dengan efikasi diri yang tinggi memiliki hasil belajar materi asam dan basa yang tinggi pula.

Pembelajaran di kelas eksperimen di awali dengan penjelasan materi oleh pendidik dan dilanjutkan dengan diskusi kelompok. Peserta didik diminta untuk mengakses materi asam basa melalui media android saat diskusi berlangsung dan menjawab latihan soal yang terdapat dalam media pembelajaran kimia berbasis android tersebut. Penggunaan media pembelajaran android mampu memberikan kesempatan peserta didik untuk menemukan konsep-konsep materi secara mandiri dan meningkatkan pemahaman konsep peserta didik sehingga media pembelajaran ini sangat layak diterapkan dalam pembelajaran. Media tersebut juga dapat membangun dan melatih peserta didik untuk mempelajari materi secara mendalam dan memberikan pembelajaran yang bermakna (Leow \& Neo, 2014).

Penerapan media pembelajaran kimia berbasis android ini mampu mengatasi kurangnya media pembelajaran di SMAN 5 Yogyakarta. Peserta didik pada kelas eksperimen mengerjakan latihan soal yang terdapat dalam media dengan sungguh-sungguh, mempelajari kembali materi asam basa yang belum dipahami melalui media, dan aktif bertanya kepada pendidik atau teman pada saat diskusi kelompok. Pembelajaran kimia menggunakan media pembelajaran android dapat membuat peserta didik tertarik dan lebih aktif dalam mengikuti pembelajaran. Peserta didik dengan kepercayaan diri yang tinggi akan terus berusaha menyelesaikan semua games dengan level yang sulit sehingga dapat meningkatkan efikasi diri peserta didik. Apabila peserta didik belum mampu menyelesaikan semua games, peserta didik dapat mengakses kembali materi pembelajaran melalui perangkat android dan mengulang kembali materi hingga peserta didik lebih memahami materi yang disajikan.

Skor efikasi diri peserta didik pada kelas kontrol yang melakukan pembelajaran konvensional memiliki skor efikasi yang rendah dibandingkan dengan kelas eksperimen. Hal ini disebabkan karena pembelajaran pada kelas kontrol diawali dengan penjelasan pendidik dan latihan soal dengan buku cetak kimia kelas XI. Pada saat pembelajaran berlansung, peserta didik pada kelas kontrol tidak aktif bertanya dan hanya menerima langsung materi yang disampaikan pendidik tanpa adanya usaha peserta didik untuk mencari materi dari sumber lain sehingga pemahaman peserta didik pada materi asam dan basa rendah yang dapat mempengaruhi hasil belajar dan efikasi diri peserta didik. Peserta didik dengan efikasi diri yang rendah cenderung mudah menyerah dan tidak memiliki keyakinan mampu melakukan pekerjaan yang menantang tersebut (Ghufron \& Suminta, 2013; Santrock, 2011; Zimmerman, 2000).

Untuk mengetahui dampak media terhadap efikasi diri peserta didik dilakukan uji ANOVA. Data yang digunakan pada uji ANOVA merupakan skor efikasi diri peserta didik yang sudah dikonversikan menjadi data successive interval. Uji ANOVA dilakukan apabila uji prasayat (normalitas dan homogenitas) terpenuhi. Normalitas distribusi data efikasi diri peserta didik dalam kelompok eksperimen dan kelompok kontrol diuji menggunakan Uji Shapiro-Wilk. Homogenitas data varians diuji menggunakan Levene's Test of Equality of Error Variance. Hasil uji normalitas tertera pada Tabel 3.

Jurnal Tadris Kimiya 4, 2 (Desember 2019): 147-156

This is an open access article under CC-BY-SA license (https://creativecommons.org/licenses/by-sa/4.0/) 
Tabel 3. Hasil Uji Normalitas

\begin{tabular}{|l|c|c|}
\hline \multicolumn{1}{|c|}{ Kelas } & N & Sig. uji Shapiro-Wilk \\
\hline Eksperimen & 33 & 0,427 \\
\hline Kontrol & 32 & 0,256 \\
\hline
\end{tabular}

Berdasarkan Tabel 3, data skor efikasi diri peserta didik pada kelas eksperimen dan kontrol berdistribusi normal. $\mathrm{Hal}$ ini ditunjukkan pada nilai signifikansi $>0,05$ yaitu 0,427 pada kelas ekperimen dan 0,256 pada kelas kontrol. Adapun hasil homogenitas varians dengan Levene's Test tertera Tabel 4.
Tabel 4. Hasil Homogenitas Varians dengan Levene's Test

\begin{tabular}{|c|l|c|c|}
\hline Variabel & Kelas & $\begin{array}{c}\text { Levene } \\
\text { Statistic }\end{array}$ & Sig. \\
\hline Efikasi Diri & $\begin{array}{l}\text { Based on } \\
\text { Mean }\end{array}$ & 0,550 & 0,220 \\
\hline
\end{tabular}

Berdasarkan Tabel 4, homogenitas data varians adalah homogen. Hal ini dibuktikan dengan nilai signifikansi dari uji homogenitas $>0,05$ yaitu 0,222. Berdasarkan karakteristik data tersebut, data skor efikasi diri peserta didik dapat dianalisis dengan ANOVA. Hasil analisis uji ANOVA dapat dilihat pada Tabel 5.

Tabel 5. Hasil Uji One Way ANOVA

\begin{tabular}{|c|c|c|c|c|c|}
\hline & Sum of Square & Df & $\begin{array}{c}\text { Mean } \\
\text { Square }\end{array}$ & F & Sig \\
\hline $\begin{array}{c}\text { Beetween } \\
\text { Group }\end{array}$ & 1140,307 & 1 & $\begin{array}{c}1140,30 \\
7\end{array}$ & 6,049 & 0,017 \\
\hline $\begin{array}{c}\text { Within } \\
\text { Group }\end{array}$ & 11875,268 & 63 & 188,496 & & \\
\hline Total & 13015,575 & 64 & & & \\
\hline
\end{tabular}

Berdasarkan Tabel 5, nilai signifikansi pada uji ANOVA sebesar 0,017<0,05 yang menunjukkan bahwa adanya perbedaan yang signifikan antara kelas eksperimen dan kelas kontrol. Efikasi diri peserta didik yang menerapkan pembelajaran dengan media pembelajaran android lebih baik daripada peserta didik yang melakukan pembelajaran konvensional.

Penggunaan media pembelajaran android memiliki efek yang signifikan terhadap efikasi diri peserta didik dalam belajar kimia. Hal ini dibuktikan dengan skor efikasi diri peserta didik pada kelas eksperimen lebih baik daripada skor efikasi diri pada kelas kontrol. Hasil penelitian ini serupa dengan penelitian yang dilakukan oleh Chen (2014) yang menunjukkan bahwa peserta didik yang menggunakan teknologi dalam pembelajaran memiliki efikasi diri yang tinggi dan menerima adanya media pembelajaran berbasis teknologi sehingga media pembelajaran berbasis android dapat dimanfaatkan sebagai media yang efektif dan efisien dalam meningkatkan efikasi diri peserta didik.

Pembelajaran menggunakan teknologi dapat mempengaruhi efikasi diri peserta didik dan prestasi belajar peserta didik (Abulibdeh \& Hassan, 2011). Peserta didik percaya dengan menggunakan media pembelajaran berbasis teknologi dalam pembelajaran mempermudah memahami materi sehingga efikasi diri menjadi lebih baik (Fitriyana et al., 2018). 


\section{KESIMPULAN}

Berdasarkan hasil penelitian ini dapat disimpulkan bahwa efikasi diri peserta didik yang melakukan pembelajaran menggunakan media android lebih baik dibandingkan peserta didik yang belajar dengan pembelajaran konvensional. Penerapan media pembelajaran kimia berbasis android memiliki pengaruh yang signifikan terhadap efikasi diri peserta didik dalam pembelajaran kimia. Hal ini ditunjukkan pada nilai signifikansi dari uji One Way ANOVA $<0,05$ yaitu 0,017. Sehingga media pembelajaran android dapat meningkatkan efikasi diri peserta didik dalam pembelajaran kimia. 


\section{DAFTAR PUSTAKA}

Abulibdeh, E. S., \& Hassan, S. S. S. (2011). ELearning Interactions, Information Technology Self Efficacy and Student Achievement at The University of Sharjah, UAE. Australasian Journal of Educational Technology, 27(6).

Amry, U. W., Rahayu, S., \& Yahmin, Y. (2017). Analisis Miskonsepsi Asam Basa pada Pembelajaran Konvensional dan Dual Situated Learning Model (DSLM). Jurnal Pendidikan: Teori, Penelitian, dan Pengembangan, 2(3), 385-391.

Anisa, F. \& Yuliyanto, E. (2017). Analisis Faktor yang Mempengaruhi Pembelajaran Kimia di SMA Teuku Umar Semarang. Makalah disajikan dalam Seminar Nasional Pendidikan, Sains dan Teknologi Fakultas Matematika dan Ilmu Pengetahuan Alam, di Universitas Muhammadiyah Semarang.

Baanu, T. F., Oyelekan, O. S., \& Olorundare, A. S. (2018). Self-Efficacy and Chemistry Students' Academic Achievement in Senior Secondary Schools in NorthCentral, Nigeria. MOJES: Malaysian Online Journal of Educational Sciences, 4(1), 4352.

Baran, E. (2014). A review of research on mobile learning in teacher education. Journal of Educational Technology \& Society, 17(4), 17-32.

Chairam, S., Klahan, N., \& Coll, R. K. (2015). Exploring Secondary Students' Understanding of Chemical Kinetics through Inquiry-Based Learning Activities. Eurasia Journal of Mathematics, Science \& Technology Education, 11(5).
Chen, Y. L. (2014). A Study on Student SelfEfficacy and Technology Acceptance Model Within an Online Task-based Learning Environment. Journal of Computers, 9(1), 34-43.

Eggen, P., \& Kauchak, D. (2010). Educational psychology. Windows on classrooms (Eight Edition). Boston: Pearson.

Evinola. (14 April 2019). Dilema Menjadi Guru Abad 21. Retrieved from https://www.kompasiana.com/3vin/5cb3 4bcda8bc15133766feb3/dilemamenjadi-guru-abad-21.

Fitriyana, N., Wiyarsi, A., \& Sugiyarto, K. (2018). The Profile of Students' Self-efficacy on Hidrocarbon Hybrid Learning and Android-Base-game. International Journal on New Trends in Education and Their Implications, 9(2), 1-15.

Ghufron, M. N. \& Suminta, R. R. (Juni 2013). Self-Efficacy dan Hasil Belajar Matematika: Meta-analisis. Buletin Psikologi Fakultas Psikologi Universitas Gadjah Mada, 21(1), 20-30.

Kemendikbud (2018). Kementrian Pendidikan dan Kebudayaan tahun 2013 tentang Laporan Hasil Ujian Nasional.

Leow, F. T., \& Neo, M. (2014). Interactive Multimedia Learning: Innovating Classroom Education in a Malaysian University. The Turkish Online Journal of Educational Technology, 13(2), 99-110.

Lubis, I., \& Ikhsan, J. (2015). Pengembangan Media Pembelajaran Kimia Berbasis Android untuk Meningkatkan Motivasi Belajar dan Prestasi Kognitif Peserta Didik

Jurnal Tadris Kimiya 4, 2 (Desember 2019): 147-156 
SMA. Jurnal Inovasi Pendidikan IPA, 1(2), 191-201.

Özmen, H., Demircioğlu, G., \& Coll, R., K. (2009). A Comparative Study of The Effects of a Concept Mapping Enhanced Laboratory Experience on Turkish High School Students' Understanding of Acid-base Chemistry. International Journal of Science and Mathematics Education, 7 (1), 1-24.

Purnama, R. D., Mawardi, M., \& Fadhilah, R. (2016). Analisis Kesulitan Belajar Kimia pada Materi Larutan Penyangga Siswa Kelas XI IPA 1 MAN 2 Pontianak. AR-RAZI Jurnal Ilmiah, 4(2).

Ramnarain, U., \& Ramaila, S. (2018). The relationship between chemistry selfefficacy of South African first year university students and their academic performance. Chemistry Education Research and Practice, 19(1), 60-67.

Rivalina, R. (2014). Kompetensi Teknologi Informasi dan Komunikasi Pendidik dalam Peningkatan Kualitas Pembelajaran. Jurnal Teknodik, 18(2), 165-176.

Santrock, J. W. (2011). Educational psychology. New York: The MC Graw-Hill Companies, Inc.

Shabrina, S., \& Kuswanto, H. (2018). AndroidAssisted Mobile Physics Learning Through Indonesian Batik Culture: Improving Students' Creative Thinking and Problem Solving. International Journal of Instruction, 17(4), 287-302.

Shanmugrapiya, M. (2012). Developing a Mobile Adaptive Test (MAT) in an MLearning Environment for Android based
3G Mobile Devices. International Journal on Computer Science and Engineering, 4(2), 153-161.

Sung, Y.T., Chang, K. E., \& Liu, T. C. (2016). The effects of integrating mobile devices with teaching and learning on students' learning performance: A meta-analysis and research synthesis. Computers \& Education, 94, 252-275.

Suyanti, R. D. (2010). Strategi pembelajaran kimia. Yogyakarta: Graha Ilmu.

Wahdania, Rahman, U., \& Sulasteri, S. (2017). Pengaruh Efikasi Diri dan Motivasi Terhadap Hasil Belajar Matematika Peserta Didik Kelas X SMA Negeri 1 Bulupoddo Kab. Sinjai. Jurnal Matematika dan Pembelajaran, 5(1), 68-81.

Yektyastuti, R., \& Ikhsan, J. (2016). Pengembangan Media Pembelajaran Berbasis Android pada Materi Kelarutan untuk Meningkatkan Performa Akademik Peserta Didik SMA. Jurnal Inovasi Pendidikan IPA, 2 (1), 88-99.

Zheng, Z., Cheng, J., \& Peng, J. (2015). Design and implementation of teaching system for mobile cross-platform. International Journal of Multimedia and Ubiquitous Engineering, 10(2), 287-296.

Zimmerman, B. J. (2000). Self-efficacy: An Essential Motive to Learn. Contemporary Educational Psychology, 25(1). 82-91. 